\title{
Power and Carbon Sovereignty in a Non-Traditional Capitalist State: Discourses of Carbon Trading in China
}

\author{
Alex Y. Lo and Michael Howes
}

Carbon markets emerge in the liberal-capitalist world as a product of a coalition of financial, political, and environmental actors that have common interests in turning GHG emissions reductions into a new commodity. ${ }^{1}$ Paterson argues that carbon markets have gained prominence because they have enabled the formation of such a powerful political coalition and enabled businesses to imagine a cycle of profits from these markets. ${ }^{2}$ Carbon markets flourish because they allow capital to accumulate as GHG emissions are mitigated.

This neoliberal model, supported by the discourse of economic rationalism, encounters difficulties in explaining why the idea of an emissions trading scheme (ETS) has found political energy in China. Several ETS trials are currently operating in this country and building the basis for a national ETS, which may potentially become one of the world's largest carbon markets. However, China is a nontraditional capitalist economy where the vestiges of administrative rationalism persist as an influential discourse within the state. While the economic discourse prevailed over administrative rationalism in the developed world during the 1980s, in China the struggle is still being played out. Non-state financial and environmental actors in China are not politically influential, and state actors, rather than a finance-led coalition, dominate domestic carbon markets. ${ }^{3}$ Moreover, the decision to introduce ETSs was made against unfavorable conditions: substantial economic uncertainties, strong resistance to capping emissions, weak domestic demand, and incomplete legal and regulatory systems. These constraints offered limited room for imagining cycles of economic gain.

China's attempt to run ETSs is shaped by its prior experience with carbon markets, notably those that are linked to the Clean Development Mechanism (CDM). Carbon markets allow for the transfer of capital between disparate locations to manage future outcomes, i.e., emissions that would have been produced. The acquired emissions reductions can be taken as an "offset" for

1. Bailey et al. 2011; Bumpus and Liverman 2008; Newell and Paterson 2010; Paterson 2012.

2. Paterson 2012.

3. Lo and Howes 2013. 
actual emissions, subject to specific requirements and standards that define their quality. These requirements and standards are unilaterally determined by supranational institutions, foreign government authorities, international environmental organizations, and business groups. Most carbon offsets or credits are purchased by organizations based in developed countries, and transactions occur via international exchanges in Europe and the US. Thus, these emissions reductions are legally defined, credited, and traded outside the sovereign spaces-mostly developing countries-in which they are materially produced and maintained. Discretionary power in determining what counts as emissions reductions is transferred across scale and space to the global spheres where governing authorities and corporate interests rest.

Consequently, even China finds itself a powerless player in these carbon markets. China supplies most of the emissions reductions under the CDM, but does not have parallel influence on the terms by which these reductions are defined, credited, and traded. This issue has attracted attention since international carbon prices collapsed and market environments became uncertain starting around 2008. Trading terms deteriorated as demand contracted, raising issues about compromising national interests and sovereignty associated with selling off the rights to emit GHGs abroad. Concerns over the loss of power to the Western world resurfaced within China, as discussed in this paper.

Our core argument is that these sentiments nurture collective desires for creating a Chinese national carbon market with proprietary rules and standards, in an attempt to redeem the displaced power. The linkage can be discerned in discursive terms more easily than logical ones. As shown later in this paper, key actors shift between two levels of reality without addressing the logical incoherence between their own arguments, conflating, for example, the construction of domestic markets with the CDM market, which is situated in a different regulatory context. This study adopts a discourse-analytic approach and advances new insights into how ETS has been seen as a legitimate policy option in places like China, where neoliberal systems do not prevail. The objective is to ascertain the political and economic considerations underlying the nationwide carbon-trading program.

In this article, we open up debates about carbon market development in non-liberal capitalist states. We seek to show that concerns over power displacement from the sovereign state have shaped the discursive context in which ETSs have gained popularity in China and become a defining element of its carbon trading discourse. We demonstrate how notions of power come into play and show that advocates within the country adhere to a storyline about power displacement.

This research aims to characterize the carbon trading discourse of China through systematic discourse analysis. Evidence is solicited from the Chinese print media. Reported opinion statements are grouped into analytic categories to build a political discourse of carbon trading. We explain how this discourse is 
embedded in the larger development narrative through the intuitive storyline of market power, which is tied to a concern about "carbon sovereignty."

\section{The Political Economy of Carbon Trading}

A number of authors have described carbon trading as a capitalist experiment for which the state harnesses market-based instruments for GHG mitigation to the advantage of big businesses and financiers. ${ }^{4}$ Carbon markets emerge in a neoliberal political-economic context within which tendencies for privatization, commodification, and marketization of environmental goods and services prevail. ${ }^{5}$ These markets provide opportunities both for curbing GHG emissions, and for capital accumulation through extracting profits from the production, financing, and trading of carbon emission permits. ${ }^{6}$ The neoliberal solution to the problem of climate change is to create new sites for profitable investment and economic growth. This process is dominated by big businesses supported by governments at various levels. Paterson, for example, suggests that the success of carbon trading "lies in part in its capacity to identify such a sector-financethat can grow precisely because of climate policy." ${ }^{7}$

Continuing economic growth, however, is ultimately a source of climate change. Advocating the market approach for dealing with climate change is understood as a tool for re-legitimizing a capitalist system that has come under attack. As Paterson argues, it is "a result of a search by parts of finance to relegitimize its dominance and practices. ${ }^{8}$ To the extent to which the traditional modes of capital accumulation are environmentally unsustainable, the ideal strategy is to create another form of capital that is causally linked to sustainable outcomes. Neoliberal regimes attempt to ease the tension between accumulation and legitimacy by diverting some benefits from capital accumulation to "legitimate" activities, such as decarbonization. ${ }^{9}$

These neoliberal processes of capital accumulation and re-legitimization occur in a transitioning political economy in which decarbonization becomes increasingly profitable, and. market actors are able to discern and capture the residual benefits from trading in emission reductions. Climate governance is also increasingly devolved to supranational institutions and non-state actors so that the norms of governance are determined in part by parties external to the state. The prospects for profits and non-state involvement are determined by legal provisions specified in international treaties such as the Kyoto Protocol and by regulatory regimes such as the EU's ETS. Carbon markets are seen as a

4. Meckling, 2011; Paterson, 2010, 2012.

5. Newell and Paterson, 2010.

6. Bumpus and Liverman 2008.

7. Paterson 2012, 89.

8. Paterson 2010, 357.

9. Bumpus and Liverman 2008. 
new avenue for economic growth operating by re-organizing the role and power of the state. ${ }^{10}$

The broader political economic context within which China's carbon markets gain force varies from those of the established liberal-capitalist regimes. China does not have a long history of neoliberalization of environmental policy, and political power remains centralized in Beijing. The neoliberal logic that drives the creation of carbon markets is not fully compatible with its authoritative tradition of climate change governance. ${ }^{11}$ Energy and financial industries do not play a dominant role in the rapid development of domestic carbon markets in China. ${ }^{12}$ The fact that the Chinese ETS operates within the structures of a non-traditional market economy and is governed by an authoritative state raises many important questions about the forms and implications of climate capitalism in such an incompletely neoliberalized economy.

\section{Progress of Carbon Trading in China}

Since 2005, China has been involved in carbon trading as an exporter of certified emission reductions (CERs) under the CDM, by which developed countries provide financial support to projects that cut or avoid greenhouse gas emissions in developing countries and acquire CERs to offset their own emissions and meet their net reduction targets. China is the largest supplier of CERs, currently hosting 50 percent of the projects registered under the CDM and producing 61 percent of the expected CERs from registered projects. ${ }^{13}$

Towards the end of 2010, the Chinese central government declared its ambition to establish a national ETS to curtail its growing GHG output. In 2011, the National Development and Reform Commission (NDRC) established seven ETS pilot sites across the country, including two provinces (Guangdong and Hubei) and five cities (Beijing, Shanghai, Tianjin, Chongqing, and Shenzhen), with the short-term goal of establishing a trans-regional ETS as a precursor to a national scheme. The ETS program is widely regarded as a key milestone in the history of Chinese climate policy.

Yet the Chinese government had been reluctant to introduce a national ETS and used to "deliberately avoid" considering the option of emissions trading. ${ }^{14}$ Instead, carbon taxes were the first preference, listed by the ministry of finance as a promising approach. Absolute emission caps impose physical constraints on economic growth, which may be why government officials saw an ETS as politically unattractive. ${ }^{15}$ Also, ETSs require an effective enforcement and punishment system for regulating polluters, as well as an accurate and

10. Bumpus and Liverman 2008; Newell and Paterson 2010.

11. Gilley 2012; Lo 2013.

12. Huang 2013; Lo and Howes 2013.

13. Source: http://cdm.unfccc.int/Statistics. Accessed August 23, 2014.

14. China Low Carbon Yearbook 2012, 746.

15. Zhang 2007. 
consistent system for measuring, monitoring, reporting, and verifying industrial emissions. Both systems are far from complete in China. ${ }^{16}$

The timing of China's entry into this market is also unusual. Carbon trading entered an uncertain period in 2009, when the world economy stumbled and the Copenhagen conference failed to produce substantive agreements on post-2012 Kyoto commitments. As market demand diminished and prospects of the Kyoto Protocol became uncertain, international CER buyers hesitated to bid. From the first quarter of 2011, CER prices fell nearly $€ 12$ down to record lows of less than $€ 1$ in December 2012. Exporting CDM credits proved far less profitable, and primary sellers encountered more stringent requirements from buyers. With a large number of CERs on market, China was severely affected.

China's ETS program is being created in unfavorable circumstances. Political and institutional constraints make carbon taxes a more reasonable option than ETS, and there seems to be little rationale for adopting a national ETS at this time. The scheme receives support, however, from the Chinese leadership's narrative that an ETS may prevent power displacement across scales. We sought evidence for this narrative by undertaking a discourse analysis.

\section{Environmental Discourses}

Discourse analysis allows us to understand how ideas, concepts, and narratives about a particular issue intersect, clash, and align. Discourse analysis is essential to understand why state actors in China have come to see carbon trading and national development as compatible.

Changes in the terms by which aspects of nature and nature-human relations are understood, represented, and discussed have led to joint problemsolving agreements and actions in politics and society at large. ${ }^{17}$ These terms, shared by multiple actors, form the basis of discourse. According to Dryzek:

A discourse is a shared way of apprehending the world. Embedded in language, it enables those who subscribe to it to interpret bits of information and put them together into coherent stories or accounts ... Each discourse rests on assumptions, judgments, and contentions that provide the basic terms for analysis, debates, agreements, and disagreements. ${ }^{18}$

Through discourses, actors give meaning to physical and social realities. These shared meanings, in turn, shape the ways in which discourses are deconstructed and reconstructed.

Discourses allow re-interpretation and rhetorical transformation of realities and policy priorities in ways beyond that of science and factual evidence. ${ }^{19}$ The

16. Han et al. 2012.

17. Dryzek 2005; Fischer 2003; Hajer 1995.

18. Dryzek 2005, 9.

19. Carvalho 2005; Dryzek and Lo 2015; Fischer 2003. 
production and re-production of shared terms for analysis and debate are pivotal to the formation of a "discourse coalition" that can interpret the divergent framings of an issue to identify a cognitive or discursive structure common to different parties, suggesting that they belong together. ${ }^{20}$ According to Hajer, the political power of the textual or linguistic representation of a discourse is not derived from its consistency, but from its "multi-interpretability." Realities may become multiinterpretable when they are effectively expressed through "storylines," defined as "narratives on social reality through which elements from many different domains are combined," providing "actors with a set of symbolic references that suggest a common understanding." ${ }^{21}$ Multi-interpretable storylines help actors coordinate their diverging understandings, connect existing interpretations, and form coalitions in the absence of shared knowledge or beliefs.

Hajer, for example, has shown that the storyline of acid rain enabled redefinition of the air pollution problem in Europe. ${ }^{22}$ The death of fish and trees used to be understood as a natural phenomenon. Through the storyline, acid rain was discursively linked to human damage to the environment. This storyline successfully represented air pollution as a threat to nature, rather than a localized industrial and/or health issue. It facilitated communication linked to previously unrelated discourses (namely, environmental degradation and industrial inefficiency). A new discourse-ecological modernization-emerged because actors now saw environmental degradation as a problem that could be dealt with by reorganizing inefficient industrial practice. This understanding led to the formation of a discourse coalition.

The discourse approach recognizes that actors have vague, contradictory, and unstable normative positions and preferences. New discourses allow them to re-present conflicting ideas as part of a storyline to achieve a particular political or social objective. The emphasis on discursive space and appearance justifies using a discourse approach for the present study, for several reasons.

First, carbon trading is a contested concept in China. It poses ideological and institutional challenges to authorities caught in the discursive struggle between economic and administrative rationalities. Official documents do not explain why an ETS policy is adopted when carbon taxes clearly have many advantages. The tension, however, can be reconciled in a discursive space by re-presenting the contested issues in new terms and in appropriate political language. Second, official policy documents in China are typically short and vague. Detailed policy proposals or legislative papers that document the reasons for adopting carbon trading and how it would operate are generally not publicly available. The policy does not exist in the form of substantive and visible policy papers, government websites, or media statements. Most people, including stakeholders, do not really see the policy system, which exists only in 
a discursive space. ${ }^{23}$ This is more so in China, where there is no clear distinction between political rhetoric and policy prescriptions.

These constraints suggest that an inquiry into what (suddenly) makes carbon trading an attractive policy option cannot fully rely on a survey of objective evidence, such as official announcements and published policy guidelines. Instead, this article investigates how concerned actors, including government officials and industry stakeholders, comprehend and discuss carbon trading.

\section{Methods}

\section{Analytical Framework}

John Dryzek's discourse-analytic framework is used to systematically identify the terms in which an environmental issue is expressed, represented, and debated. ${ }^{24}$ The framework has two levels of analysis. The primary level consists of four political discourse elements: basic entities (the entities whose existence is recognized or constructed), natural relationships (the relationships between different entities that are deemed to be natural or unnatural), agents and their motives, and metaphors ${ }^{25}$ The secondary level of analysis applies to the study of utterances regarding a political issue. Political discourses always embody certain claims about the world. The types of claims made-definitive, designative, evaluative, and advocative-can further distinguish between political expressions. ${ }^{26}$

We largely adopted this bi-dimensional analytical schema but omitted metaphors. The use of metaphors in Chinese newspapers is occasional and sporadic, and our initial research managed to identify only a handful. We replaced metaphors with perceptions of "capacity for change," defined as the perceived ability of an action or a process to make relationships between entities or actors more natural or unnatural. This refers to the perceptions of what factors either preclude or facilitate a preferred change. "Capacity for change" concerns practical solutions and emphasizes functional qualities, for example with respect to the role of direct regulation, market mechanisms, and political negotiations.

Our analytical schema generated a four-by-four matrix for sampling. We created a matrix table by reducing each political discourse element to four categories according to the type of claim (Table 1). Statements for analysis were solicited and allotted to one or two of the sixteen cells.

\section{Data Collection}

We sought to ascertain how carbon trading is understood, represented, and discussed as a policy concept. Our sampling strategy focused on the arguments and

23. Fischer 2003.

24. Dryzek 2005.

25. Dryzek 2005, 17-19.

26. Dryzek and Berejikian 1993. 
Table 1

Sampling Schema for Discourse Analysis

\begin{tabular}{|c|c|c|c|c|}
\hline \multirow[b]{2}{*}{ Type of Claim } & \multicolumn{4}{|c|}{ Discourse Element } \\
\hline & $\begin{array}{l}\text { Basic Entities } \\
\text { (what is } \\
\text { recognized) }\end{array}$ & $\begin{array}{l}\text { Natural } \\
\text { Relationships } \\
\text { (how things } \\
\text { relate) }\end{array}$ & $\begin{array}{l}\text { Agents and } \\
\text { Motives (who } \\
\text { and why) }\end{array}$ & $\begin{array}{l}\text { Capacity } \\
\text { for Change } \\
\text { (what makes } \\
\text { things work) }\end{array}$ \\
\hline Definitive & A1 & B1 & $\mathrm{C} 1$ & D1 \\
\hline Designative & A2 & B2 & $\mathrm{C} 2$ & D2 \\
\hline Evaluative & A3 & B3 & C3 & D3 \\
\hline Advocative & A4 & B4 & $\mathrm{C} 4$ & D4 \\
\hline
\end{tabular}

Adapted from Dryzek and Berejikian 1993.

knowledge claims of the concerned actors. Discourse analysis requires a broadbased sampling strategy to cover a wide range of reported views expressed by actors from different sectors and various levels. Thus, we included sources from mainstream national newspapers as well as tabloid-style local, industrial, and specialist newspapers. We paid particular attention to those statements indicating specific discourse elements, such as the nature of markets and the relationships between nations.

We accessed news articles via a professional Chinese digital database known as the China National Knowledge Infrastructure (CNKI). The CNKI makes full texts of a variety of digitalized publications available for subscribers, including 592 different newspapers ranging from national to local, sector-based, and thematic publications. Only print media published in Mainland China and written in Chinese were included in the initial search.

We searched for news articles using four Chinese keywords that are directly related to carbon trading, namely, "carbon trading (tàn jiāo yì)," "carbon emission trading (tàn pái fàng jiāo yì)," "carbon market (tàn shì chăng)," and "carbon emission market. (tàn pái fàng shì chăng)." Only articles published from July 1, 2008, to June 30, 2013, were included. The start date was chosen because in mid-2008 several local carbon exchanges emerged that indicated where in China the domestic market was emerging. ${ }^{27}$ The end date marked the start of pilot ETSs. The selected search period therefore captured the transition from initial market development to institutionalization. These procedures returned 703 news articles.

To avoid missing information, we ran an additional search using a popular Chinese online search engine called Baidu. This yielded an additional 58 articles, which were reduced to 46 by screening out duplicate reports. The sample was further sorted to remove irrelevant topics such as carbon market activities of 
other countries and descriptive industrial briefs. As a result 143 articles were excluded, leaving a pool of 606.

To extract a manageable number of articles (about 30 percent) from the pool, we sorted the articles chronologically, starting from the oldest, selecting every third or fourth article. Thus we shortlisted 179 articles for detailed textual analysis. Each was scrutinized using the discourse-analytic framework. Statements that directly refer to carbon trading or markets in China and report arguments or claims of concerned actors that indicate a discourse element were coded into relevant analytic categories (as listed in Table 1). Our search mainly focused on reported interviews and discussions involving key actors such as industry representatives, government officials, journalists, and academics.

\section{Basic Entities}

We outline our research results by presenting representative statements entered into each analytic account that denote the arguments and claims of actors concerned. The first numbers in brackets below (e.g., \#21) refer to the article numbers listed in Appendix, and the two-digit codes that follow them (e.g., A1) are the cell identifiers in Table 1.

\section{The Key Problem: Loss of Power}

Our analysis revealed that actors frequently raise the issue of market power as a concern. The policy implications of carbon trading are often couched in terms of various forms of "power" that are tied to the prospects for national development. Speaking on carbon trading, a government official from the NDRC suggested:

Securing the power of setting the rules-of-the-game means securing the power of maintaining national development. (\#21 A1)

This view underlies the framework in which carbon trading is being developed. The carbon trading discourse portrays an image of national interests being compromised by the collapse of international carbon prices over the last few years.

Currently the biggest challenge for [the Chinese] domestic carbon markets is the steep decline in trading prices. (\#11 A2)

Falling prices pose a major challenge because China currently lacks "pricing power" (dìng jià quán) in existing carbon markets:

National interests are severely damaged because our country does not have pricing power in the international carbon markets. (\#92 A3)

Pricing power can be broadly understood as the ability to negotiate favorable terms of trade (related to the economic concept of price-making). Currently, the 
terms by which carbon emissions are traded (such as compliance regulations, pricing rules, and carbon credits verification standards) are predominantly determined by industrialized economies. China does not have much capacity for determining these regulations, rules, and standards, and consequently only has a price-taker role. The limited capacity contributes to the problem of declining pricing power:

If China doesn't set up [carbon] exchanges, we will lose the pricing power in carbon trading and remain in a passive role. (\#19 A3)

Because we don't have our own trading system, we can't get the pricing power. (\#108 A2)

In some cases, the pricing power is expressed in another form-the "power of saying" (huà yǔ quán)—which literally means the ability to have a say in the carbon markets:

If you [i.e., China] don't speak and act, you are likely to lose the power of saying. In the future, you can only stay at the lower end of the market, without the rights of participating, decision-making and pricing. (\#22 A3)

These power-related keywords are repeated in a number of news articles over time to describe a pressing problem. They are consistently linked to national development interests and articulated as a supporting argument for creating a domestic carbon market. This is clearest in statements that explicitly mention power and carbon markets.

\section{Strengthening the Market to Secure Market Power}

Concerns over the loss of pricing power have prompted moves to set up a national carbon market that would enable China to influence the terms of trade in the international carbon markets. The following quotes indicate a perceived causal relationship between domestic carbon market and pricing power:

China should speed up the process of establishing carbon exchanges in order to protect the interests of domestic markets. This will also strengthen our negotiating power. (\#1 A4)

China has a huge emissions market but not pricing power ... that's why provinces compete to set up their own carbon markets. (\#6 A2)

The lagging-behind carbon markets ... could affect our country's ability to secure pricing power and gain initiative in the international carbon markets. (\#130 A3)

The loss of pricing power and the power of saying is a pragmatic reason for China to build up carbon markets. (\#144 A2)

There is a widespread belief that building a stronger domestic market is essential for China to strengthen its international market power. What, however, are the 
sources of this market power? In carbon markets, verified emissions reductions are a form of capital. In theory, the more emissions a country produces and the greater the potential for turning them into a tradable commodity, the greater the market share and the larger the economic gains the country could potentially secure. It is believed that large volumes of GHG emissions could support the burgeoning carbon market and provide new energy to domestic and global economies:

Currently China emissions reductions account for one-third of the total volume in the global market. By 2012, China will take up 41 percent in all U.N. indicators. China has great prospects for carbon trading in the future international markets. (\#72 A3)

This suggests that carbon trading is seen as beneficial because it can turn GHG emissions into economic opportunities. The high level of Chinese GHG emissions is seen as a potential for augmenting its market share, thus illustrating the perversity of externalities, where something that is bad for the environment is good for the economy.

Concerned actors have articulated a two-level logical relationship between the market, power, and national development: establishing a functioning domestic carbon market is seen as a way to strengthen pricing power, which is important for protecting national interests in the international carbon markets. Through the discursive window of carbon trading, China's large volumes of GHG emissions are viewed as a powerful market driver that can create a huge market share and contribute to its market power. These notions of power crucially enable an extended interpretation of carbon trading in broader politicaleconomic terms, particularly with regards to development rights and wider economic influence, both of which are closely linked to national interests. The linkage between power and development is more clearly reflected in the assumptions about (un)natural relationships between developed and developing countries.

\section{Natural Relationships}

\section{Power Imbalance in the Global Context}

Building a domestic carbon market is important for development because international carbon market conditions perpetuate what is seen as an unnatural relationship that precludes the realization of development benefits by China. The international context in which carbon trading is discussed portrays the view of a competitive relationship between China and the developed world:

Global carbon trading has become a scramble like "dancing with the wolf." The functioning of [our] carbon trading system directly affects our country's destiny in the fierce competition for global carbon trades. (\#167 B1) 
Although the prospects for carbon trading are good, there are no gains for China, whose current domestic market remains uncompetitive:

The [Chinese] markets are chaotic; entities are fragmented; negotiating power is weak. China's carbon markets fall well behind the international carbon markets. (\#1 B3)

Some of these hurdles stem from China's own institutional failures; others are produced by unequal global power structures. The conviction that China has suffered from the hegemony of the Western world is firmly embedded in the arguments for strengthening engagement in carbon trading. A key unnatural aspect is reflected in the passive role of China under the CDM:

China can't get the power of saying as developed countries set the rules of the CDM. (\#62 B2)

China accounts for 60 percent of the market share under the CDM. That's why developed countries impose more restrictions on China. (\#100 B3)

What is regarded as unnatural is China's carbon trading opportunities being unduly compromised by its perceived hegemonic rivals in the global context. The lack of competitiveness and excessive restrictions suggest an unwelcome power imbalance between carbon trading countries. Concerns over this power imbalance have motivated attempts to redeem "carbon sovereignty."

\section{Securing Carbon Sovereignty and Autonomy}

The narrative of power imbalance provides discursive resources for a dialectic struggle around what we call "carbon sovereignty." Although China has become a major global economy, it paradoxically sees itself as powerless in the competitive carbon market. This perceived powerlessness contradicts the knowledge that China has risen to become the dominant supplier in these markets:

Although China has become the largest seller, we don't have pricing power in this market. (\#23 B2)

Our country is the largest $\mathrm{CO}_{2}$ producer and emitter. We should have a say on prices. (\#50 B4)

China has become the largest supplier of verified emissions reduction in primary market, but remains a "price-powerless" country. (\#62 B1)

This indicates a dominance-powerlessness paradox. In international carbon markets, China currently dominates production but not governance. Chinese actors are frustrated by the lack of material influence, which they believe should have come naturally with the rising prominence and the expanding scale of their economy. International market conditions perpetuate existing inequalities between the prospering China and the developed world. The discrepancy 
between expectation and reality prompts a search for solutions to "naturalize" the relationships.

Therefore, active engagement in the carbon market is regarded not only as a way to defend China's material interests, but also to alter an unnatural relationship and rescue the core entity-pricing power-from the perceived hegemony of Western climate capitalism. Active engagement and ontological independence are articulated in terms of a cause-effect relationship:

Setting up Chinese-made voluntary emissions reduction standards can help enhance our autonomy and independence in the international emissions reduction market. (\#52 B4)

Our country must set up our own national carbon trading market as soon as possible. Otherwise we would be restricted to a passive role when western countries make troubles using measures such as carbon tariffs. ${ }^{28}$ (\#121 B4)

The power of saying brings about pricing power. Only by strengthening pricing power can we be free from the restrictions imposed by others in the international carbon markets. (\#144 B1)

The subjective logic is that by strengthening the domestic carbon market, China could regain sovereignty and autonomy from the developed world, which currently holds authority over trading rules, pricing mechanisms, and verification standards.

To summarize, our analysis shows that Chinese actors consider a functioning domestic trading system to be crucial for strengthening China's capacity to influence trading rules and prices. The country's development interests have been compromised by the existing unequal power structure perpetuated in the international carbon markets. Securing market power is seen as a way to alter this unnatural relationship.

\section{Agents and Motives}

Although notions of power underpin the arguments for carbon trading, market conditions call into question the use of this policy approach. China has neither strong market demand nor a robust regulatory system for supporting cap-and-trade policies. One reason is the low motivation of key agents, notably firms.

Few Chinese firms volunteer to curb their GHG emissions and purchase carbon credits. The Chinese business sector largely remains self-interested,

28. This is not a factually coherent statement, because carbon markets and carbon tariffs operate on very different policy platforms and do not directly depend on each other. The tension indicates a logical incoherence of the discourse and raises question about using rationalistic analysis to understand the policy preference, as we argue in the Discussion. 
pursuing short-term profits, and has not seen corporate social responsibility as its priority:

We don't expect businesses participate in the CDM for the purpose of saving the Earth. Making profits is their nature. (\#15 C1)

At present domestic carbon buyers are largely firms or individuals who seek to fulfill their social responsibility. So the scale of the [voluntary] market remains limited. (\#78 C2)

Businesses engage in carbon trading either for the purpose of complying with binding emission reduction requirements or voluntarily fulfilling their corporate social responsibility undertakings. The absence of emission caps along with limited voluntary commitments have weakened market demand for emissions reductions. Consequently the scale of domestic voluntary carbon markets is diminished:

Local governments and businesses have no motivation to act in the absence of mandatory emission targets. The market won't exist. (\#110 C2)

Businesses have little motivation and there is a shortage of market demand for carbon trading. (\#106 C2)

In addition, businesses do not have the expertise or knowledge to participate in carbon trading. Some are discouraged by the incomplete market structure and centralized policy-making practices in China. Here again we see the struggle between economic rationalism and administrative rationalism. Although they are key agents in this clash of discourses, businesses are not seen as the main driver of market development.

Instead, local governments drive market development-as economic competition among Chinese provinces and cities is quite intense. Local governments compete to establish carbon exchanges and participate in carbon trading in an attempt to make their jurisdictions a domestic carbon financial center:

Local governments are keen on setting up carbon exchanges because of the competition among them and the driver of material gains. This is a bandwagon phenomenon where governments compete to step in first in order to secure material benefits for local pockets from national authorities. (\#79 C2)

Competing to become a carbon financial center is the key motivation of local governments [to participate in carbon trading]. (\#94 C1)

This competition, however, has not produced successful outcomes. The domestic market remains illiquid as transactions are limited. ${ }^{29}$ Carbon trading requires 
new forms of institutions that are typically more complex in practice than local governments in China can handle.

The central government is facing a dilemma. It has recently decided to run "cap-and-trade" experiments in selected sites, but the decision stands at odds with the fact that it currently does not accept binding caps on absolute emissions at the national level. Although actors tend to support the official skepticism toward binding targets, they believe that China, being a major economy, has undeniable responsibilities for mitigating climate change. They still, however, take for granted continuing growth in absolute emissions. This discourse portrays China as a rising world power deeply torn between accepted climate responsibility and development imperatives. These motives are seen as conflicting and imply tension and ambiguity in agency. Such contradictions are also observed in the discussions on capacity for change.

\section{Capacity for Change}

A broadly held view is that binding rules and effective regulation are essential to constructing and operating carbon markets. The need for institutional capacitybuilding is closely tied to notions of market power:

[By running pilot ETSs, China can] establish a more complete and effective trading system. Building upon such market advantages, we can reclaim pricing power from international and regional carbon markets. (\#154 D4)

Actors are not convinced, however, that China has the capacity to create and enforce such rules and regulations. Although building a carbon market is viewed as an imperative, it is well recognized that the domestic environment currently does not favor carbon trading. Some government officials doubt that China has a solid institutional basis for carbon trading. Financial actors have expressed similar views; for example the head of the Shanghai environment exchange indicated that "carbon trading is foreseeable, but carbon finance is too early" (\#110 D3), meaning that carbon financial services are far from adequate. These concerns stem from two key problems with the present institutional context.

First, Chinese carbon markets operate in the absence of absolute emission caps, which are essential for creating scarcity of emissions allowances and supporting appropriate pricing. On this issue the actions of the central government itself lack consistency. In the early 2011 (if not 2010), the Chinese government officially put carbon trading on agenda, but at around the same time, in late 2010, a senior NDRC official overseeing the country's climate change policies indicated that:

China has not specified a target for reduction in absolute emissions. There is no basis for implementing carbon trading. (\#64 D2) 
There is a widespread awareness that the absence of emissions caps is the most critical barrier to strengthening the domestic carbon markets:

Since we haven't specified an absolute emissions limit, it is premature to create a market for carbon trading in our country. (\#60 D2)

Mandatory absolute limits are necessary for creating a national [carbon] trading market. Otherwise there wouldn't be any trading activity. (\#90 D1)

Without mandatory emissions limits, carbon trading is not going to work. (\#106 D3)

Given that businesses are not motivated to take voluntary actions, mandatory targets are needed to drive the carbon markets. Like pricing power, emissions capping has been a repeating theme in the reported interviews and discussions, suggesting that there are widespread concerns over the issue, especially given the failure of the central government to impose an absolute cap.

Second, the current regulatory regime for carbon trading is considered primitive and inefficient. Transaction costs are prohibitive due to excessive administrative procedures. Legal systems are incomplete, guidelines are unclear, and enforcement is far from effective. A particularly important issue is the monitoring, reporting, and verification of emissions from firms. Some of the legal and regulatory deficiencies are aggravated by the "reckless" competition between local governments:

Local governments competing for setting up carbon exchanges are likely to result in inconsistent standards, low trading volumes and the shortage of buyers. (\#78 D3)

At present, domestic carbon exchanges are set up by local governments. There are problems such as absence of national policy support, reckless development with no plan for future, and local protectionism, etc. These not only contribute to failures in creating a carbon trading industry in our country, but also cause regulatory chaos and misuse of resources. (\#102 D3)

Such structural governance problems are another repeated theme reported in our sample and have been expressed by government officials themselves.

The absence of emissions caps and the incomplete regulatory regime both stem from failures of key agents to define and formulate rules or guidelines to drive and discipline market behavior. These institutional deficits are a function of agency. The capacity for change and agency are interrelated structural conditions that impede the development of carbon markets in China. These realities frustrate the prospects of carbon trading in China and undermine the rationale for implementing cap-and-trade systems in the near future. 


\section{Discussion: The Role of the Market Power Storyline}

China's carbon trading discourse has two core components. The first is couched in terms of national (or nationalist) aspirations-the endeavor for power and equality in the context of global carbon trading-that underpin the most important ontological and relational elements of the discourse. The second concerns practical considerations, namely, the belief that domestic agents and institutions are not ready for taking on carbon trading, which underpins the agency and capacity dimensions of the discourse.

The practical considerations describe the unfavorable realities associated with the implementation of carbon trading mechanisms. Concerned actors are aware that China currently does not offer a favorable environment for running a national carbon trading system. Market regulation, governance, and the macroeconomic implications of emissions caps all pose challenges. Given these regulatory and economic adversities, carbon trading mechanisms are unlikely to directly generate material economic benefits for the country. From a purely regulatory and economic perspective, the carbon trading discourse is not linked to the appealing narrative of national development in a positive way.

The market power storyline demonstrates the intimate linkage between ETS and development narratives. Our analysis is schematically summarized in Figure 1: the lack of institutional capacity makes China uncompetitive in international carbon markets. This disadvantaged position is perpetuated by the distorted and unequal power structure embedded in the carbon markets, which have been dominated by Western institutions currently holding the power of determining terms of trading. This sentiment is underpinned by a "big country" mentality-the conviction that China, as a major economy, should have a "say" on matters concerning global carbon trading, and share the rule-making power with major developed economies. The perceived reality, however, is that China has lost its carbon sovereignty, which is seen as an indicator of national development progress, in the international markets (by being a price taker in poor market conditions). Collective expectations and reality are torn apart by those practical considerations, but the conflict is discursively reconcilable by invoking a constructive storyline.

Market power is the powerful storyline that is amenable to concerns about carbon market, power structure, and national development. It is frequently mentioned and expressed in various forms, most commonly "pricing power" (i.e., price making) and "power of saying." On the one hand, a strong influence on international affairs is an integral component of China's national development discourse. Existing carbon markets are becoming an important globalizing market. The ability to influence carbon prices and trading rules is couched by Chinese actors in terms of global political-economic power and broader development imperatives. On the other hand, the strength of market power depends on market share and a functioning market system. Establishing a domestic 


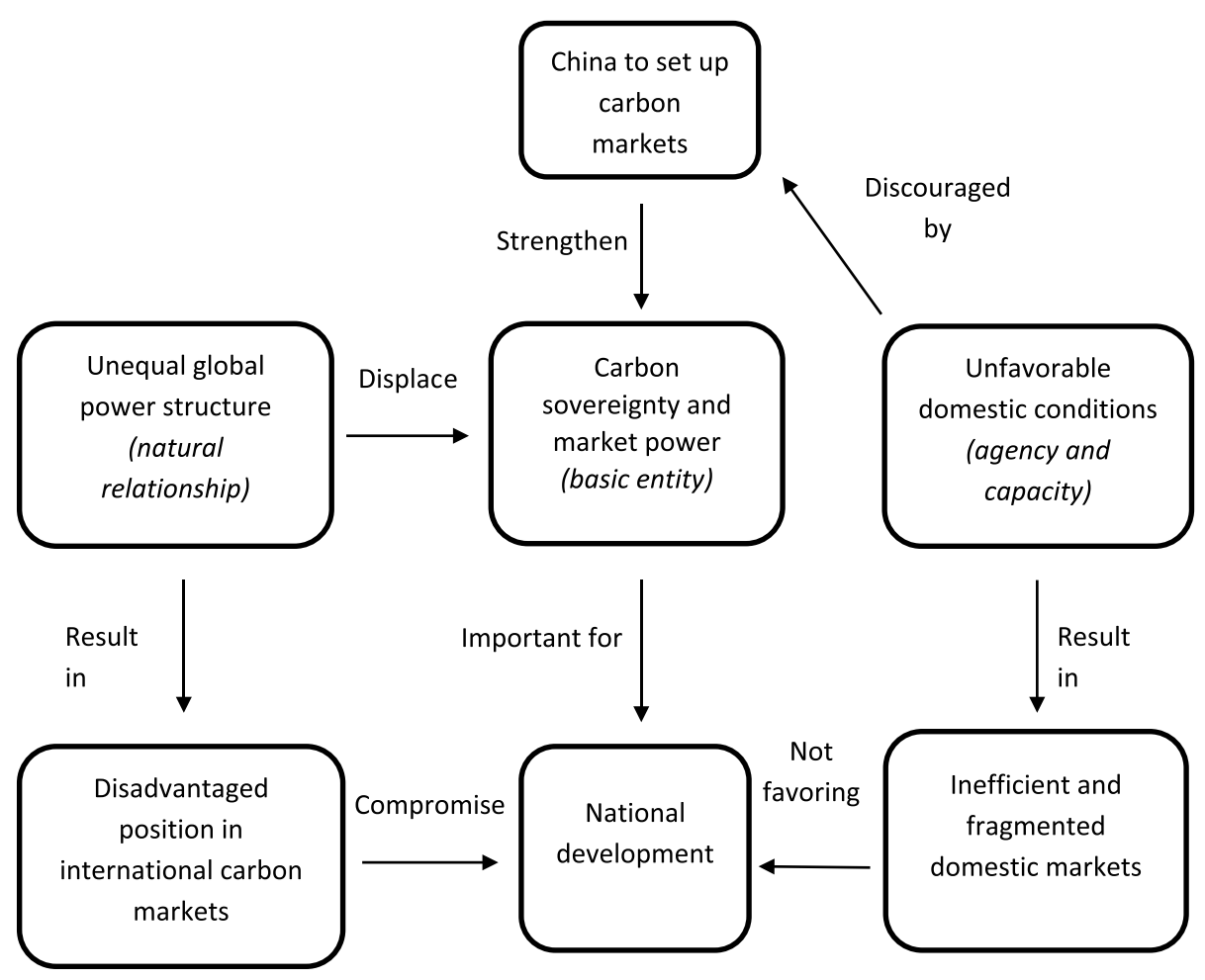

Figure 1

Schematic Representation of the Carbon Trading Discourse of China

carbon market is now seen as a necessary step to gain influence on the making of rules and prices in the regional and international markets. Active engagement in carbon trading is understood in terms of building capacity for strengthening market power. Thus, establishing a domestic carbon market is seen as an institutional condition for securing market power, and the aspiration for such power is embedded in the narrative of national development. This storyline discursively bridges the realities of carbon markets and the narrative of national development.

Following Hajer and Versteeg, ${ }^{30}$ we argue that the substantive support carbon trading has received in China cannot be the result of a rational analysis of the material benefits it could bring: discourses contain inconsistencies. One inconsistency in this case is that Chinese actors expect and accept continuing growth in absolute emissions, which could, however, call into question the use of quantity-based instruments such as cap-and-trade mechanisms. Second, the widespread belief that China is not ready for carbon trading does not 
prevent actors from supporting it in practice. Key actors, including policymakers, have raised concern about the capacity for supporting large-scale carbon trading. Such incoherence can be discerned from the observation that actors do not appear to distinguish between allowance-based markets (e.g., ETS) and project-based markets (e.g., CDM). This suggests that they, perhaps unknowingly, shift between two different realities when considering the practical challenges ahead, such as capping GHG emissions, which is not necessarily required for building a project-based market. Moreover, the external economic environment was highly uncertain when the central government decided to scale up its carbon markets. ${ }^{31}$ Carbon trading received high-level political support within China when the international carbon markets were unsettled. Adopting the policy approach at this time and place cannot be understood using rational regulatory and economic assumptions.

The policy preference for carbon markets can be deduced from the linguistically constituted symbols and narratives that govern how actors think and respond. In Chinese, "power," "sovereignty" and "rights" can all be written using the same character: quán. In China, carbon markets are often discussed in the context of pricing "power," while development is seen as a sovereign issue and a matter of "rights" to which the country is entitled for historical reasons. By invoking the multi-interpretable power storyline, active engagement in carbon trading can be understood more broadly than simply a way to strengthen state influence on a specific policy space. It can also be understood as a way to protect entitled development rights and redeem sovereignty from the unequal power structure perpetuated by international carbon markets. Notions of market power or pricing power essentially act as a constructive rhetoric that is constituted in language and allows extended interpretation by those actors who give higher priority to development than GHG mitigation. ${ }^{32}$ Without altering beliefs or fundamental values they mobilize discursive resources and facilitate communication with the development narrative, which is far more powerful and appealing in China. Notions of power provide shared terms of reference for discursive interaction and allow an extended interpretation of carbon trading that can more effectively reach those who primarily engage in the national development discourse.

\section{Conclusions}

The displacement of power is the point of departure for understanding why carbon trading has gained momentum in China. The ways in which carbon markets are governed by supranational institutions and non-state actors results in the geographical displacement of power in determining what counts as reductions from within the sovereign borders of developing countries, 
where these reductions actually materialize, to the hosts of international carbon markets, that is the developed world. This article demonstrated how concerns about this issue are articulated and related to the preference for carbon trading.

Our discourse analysis suggests that notions of market power constitute a multi-interpretable storyline in the carbon trading discourse of China. The rescaling of the governing regime, coupled with the deteriorating global economic environment, impoverished the capacity for China to have a "say" on the terms under which carbon emissions are traded. This stands at odds with China's self-recognized image as an important market player and a major world power. Perceived loss of power is central to this discourse. This sentiment has evolved into aspirations for redeeming market power and reshaping the unequal power structure perpetuated by the international carbon markets. These aspirations provide discursive energy for the storyline of market power.

The power storyline creates a positive, self-reinforcing linkage between carbon markets and the narrative of national development. It argues that establishing carbon markets can help strengthen the country's market power. Market power, on the other hand, is interpreted in terms of protecting development interests. By establishing a proprietary carbon market that would potentially take up a great deal of global market share, China could defend its interests in domestic emissions reductions, which have been compromised by the rescaling of climate governance, and redeem the displaced power that is seen as an integral part of its development narrative. Appealing to market power allows an extended interpretation of carbon trading in terms of development, which is a politically more attractive discourse in China. Through this discursive link, carbon trading can be viewed as compatible with recognized development imperatives.

The findings open up debates on the carbon market development in major non-traditional capitalist states. Carbon markets permit commodification and trading of domestic GHG emissions across space through a globalized market mechanism powered by a finance-led political coalition. ${ }^{33}$ As a non-traditional capitalist economy, however, China has opted-in without any clear intervention by such a coalition. ${ }^{34}$ The parties involved in the market building process share interests and concerns over the displacement of power in defining, pricing, and governing sovereign carbon-domestically produced emissions reductionsfrom the country. We suggest that carbon markets are deconstructed and reconstructed not merely in the service of capitalism, but to protect development interests from the capitalist hegemony. Global climate capitalism rescales climate-governing regimes to the disadvantage of those price-powerless primary producers in the market. Therefore, China's active engagement in carbon trading 
is underpinned by the struggles to develop and aspirations for strengthening the influence of the sovereign state and its economic constituency over global or regional market order.

Further research is needed to solicit direct evidence on the claims we made. Our study was based on a textual analysis of Chinese news articles and revealed the construction of meaning regarding the role of carbon markets. Such a discursive approach is useful for showing how carbon trading was construed as a legitimate policy option, but cannot empirically demonstrate the "true" motives. Direct inquiry into the rationale behind the policy choice, which might benefit from in-depth interviews with stakeholders and policymakers, can address the limitations of the present study.

\section{References}

Bailey, Ian, Andy Gouldson, and Peter Newell. 2011. Ecological Modernisation and the Governance of Carbon: A Critical Analysis. Antipode 43 (3): 682-703.

Bumpus, Adam G., and Liverman, Diana M. 2008. Accumulation by Decarbonization and the Governance of Carbon Offsets. Economic Geography 84 (2): 127-155.

Carvalho, Anabela. 2005. Representing the Politics of the Greenhouse Effect. Critical Discourse Studies 2 (1): 1-29.

China Low Carbon Yearbook. 2012. China Low Carbon Yearbook (zhongguó dì tàn nián jiàn) Beijing: China Financial and Economic Publishing House.

Dryzek, John S. 2005. The Politics of the Earth: Environmental Discourses, 2nd ed. New York: Oxford University Press.

Dryzek, John S. and Alex Y. Lo. 2015. Reason and Rhetoric in Climate Communication. Environmental Politics. http://dx.doi.org/10.1080/09644016.2014.961273.

Dryzek, John S., and Berejikian, Jefferey. 1993. Reconstructive Democratic Theory. American Political Science Review 87 (1): 48-60.

Fischer, Frank. 2003. Reframing Public Policy: Discursive Politics and Deliberative Practices. Oxford: Oxford University Press.

Gilley, Bruce. 2012. Authoritarian Environmentalism and China's Response to Climate Change. Environmental Politics 21 (2): 287-307.

Hajer, Maarten A. 1995. The Politics of Environmental Discourse Ecological Modernization and the Policy Process. New York: Oxford University Press.

Hajer, Maarten A., and Versteeg, Wytske. 2005. A Decade of Discourse Analysis of Environmental Politics: Achievements, Challenges, Perspectives. Journal of Environmental Policy and Planning 7 (3): 175-184.

Han, Guoyi, Marie Olsson, Karl Hallding, and David Lunsford. 2012. China's Carbon Emission Trading: An Overview of Current Development. Stockholm: SEI and FORES.

Huang, Yitian. 2013. Policy Experimentation and the Emergence of Domestic Voluntary Carbon Trading in China. East Asia 30 (1): 67-89.

Lo, A. Y. 2013. Carbon Trading in a Socialist Market Cconomy: Can China Make a Difference? Ecological Economics 87: 72-74.

Lo, A. Y., and Michael Howes. 2013. Powered by the State or Finance? The Organization of China's Carbon Markets. Eurasian Geography and Economics 54 (4): 386-408. 
Meckling, J. 2011. Carbon Coalitions: Business, Climate Politics, and the Rise of Emissions Trading, Cambridge, Mass: MIT Press.

Newell, Peter, and Matthew Paterson. 2010. Climate Capitalism: Global Warming and the Transformation of the Global Economy. Cambridge: Cambridge University Press.

Paterson, Matthew. 2010. Legitimation and Accumulation in Climate Change Governance. New Political Economy 15 (3): 345-368.

Paterson, Matthew. 2012. Who and What are Carbon Markets For? Politics and the Development of Climate Policy. Climate Policy 12 (1): 82-97.

Zhang, Zhongxiang. 2007. Why Has China Not Embraced a Global Cap-And-Trade Regime? Climate Policy 7: 166-170. 


\section{Appendix}

Appendix: Sources of Chinese news articles cited

No. Article title in Chinese pinyin (translation in bracket)

l shuí lái dā jiàn tàn jiāo yì píng tái ? (Who will build the carbon trading platform?)

6 tàn jiāo yì de " zhōng guó lù jìng " (Carbon trading the Chinese way)

11 zhōng guó tàn jiāo yì duăn qī shòu cuò (China's carbon trading short-term setback)

15 rén rén shēn yù tàn jiāo yì (Everyone gets involved in carbon trading)

19 zhōng guó zhèng zài chéng wéi yà zhōu tàn pái fàng jiāo yì zhōng xīn (China to become a carbon emissions trading center in Asia)

21 tàn jiāo yì : " tàn qiáng dù " yǔ " zǒng liàng kòng zhì " xián jiē shì guān jiàn (Carbon trading: transition from intensity to aggregate control is the key)

22 tàn jiāo yì : dī tàn jīng jì xià de quán xīn kè tí (Carbon trading: a Jiefang Daily new topic in the low-carbon economy)

23 tàn jiāo yì shì chăng qián jǐng kě guān (Great prospects for carbon trading markets)

50 zhēng qŭ tàn shì chăng huà yǔ quán zhù lì dī tàn jīng jì (Secure the power of saying in carbon market to boost low-carbon economy)

52 zhōng guó tàn jiāo yì shì chăng kāi tuò zhě (Pioneer of Chinese carbon market )

60 tàn jiāo yì duăn qī shì diăn wèi zhǔ duō tú jìng tuī dòng xīng huǒ liáo yuán (Pilot carbon trading in short-term, multiple ways catching the fires )

62 yè nèi rén shì chēng zhōng guó quē fá tàn pái fàng jiāo yì dìng jià huà yǔ quán (Industry says China lacking of the pricing power for carbon emissions trading)

64 wǒ guó tàn pái fàng jiāo yì tiáo jiàn shàng bù chéng shú (China's carbon emissions trading conditions are not ripe yet)

Jiefang Daily 26-Jul-08

People's Daily

02-Dec-08

Online

China Securities 23-Apr-09

Journal

China Environment 3-Jul-09

News

China Business 22-Sep-09

Herald News

Weekly

China Economic 24-Oct-09

Herald

Jiefang Daily $\quad$ 5-Nov-09

China Energy News

9-Nov-09

China Reform Daily

26-May-10

Workers Daily

9-Jun-10

China Securities

6-Sep-10

Journal

Chinanews

20-Sep-10

Beijing Business

Today

China Petroleum

Daily (Marketization stimulates carbon market development)

72 tàn jiāo yì shì chăng, xiăng shuō ài nǐ bù róng yì (Carbon market: not easy to love you)

78 tàn pái fàng jiāo yì quán zhēng duó zhàn dà mù lā kāi (Battles begin to fight for carbon trading rights)

79 tàn jiāo yì suǒ $\neq$ tàn shì chăng tàn pái fàng quán jiāo yì shàng wèi xíng chéng (Carbon exchanges $\neq$ carbon market: Carbon trading hasn't gained shape)

90 jiān guăn céng yùn niàng tàn jiāo yì shì chăng lù xiàn tú (Regulators preparing roadmaps for carbon trading market)

94 huá běi diàn wăng qū yù kě wèi tàn jiāo yì xiān xíng qū (North China power grid area for carbon trading pilots)

100 zhōng guó tàn jiāo yì miàn lín shuāng chóng yā lì (Double pressures on China's carbon trading)

102 tàn jiāo yì shì chăng xiàn shǔ guāng lín yè tàn huì huò pò jiāng jú (Carbon market comes to dawn, forest carbon sequestration may break deadlock)

106 wú mì xià guō tàn jiāo yì shì chăng nán chéng chuī (No food: carbon market can't get up)

108 zhŭn què bă wò shí tí jīng jì shì tàn shì chăng jiàn shè de jī chŭ (Getting the real economy right is the foundation of building a carbon market)

110 “ wǒ xiàn zài chŭ zài yí gè bú shòu huān yíng qī, zhèng zài wán shàn tàn jiāo yì shì chăng shè jì " ("I am not popular at the moment, while improving carbon market design")

121 jiàn lì quán guó tǒng yì de tàn jiāo yì shì chăng yĩ kè bù róng huăn (Setting up a national carbon market is an urgent issue)

Jiangsu Science and

Technology News

China Securities

Journal

People's Daily

Online

China Times

21st Century

Economic Report

Xinhua Net

26-Jul-11

11-Nov-11

China Securities

Journal

21-Nov-11

China Trade News

15-Dec-11

Chinese Social

27-Dec-11

Sciences Today

Oriental Morning

17-Jan-12

Post

China Economic

14-Apr-12

Herald

China Economic 18-Aug-12 carbon trading market takes time to get strong)

Herald

144 zēng qiáng huà yǔ quán gào bié " mài tàn wēng " (Strengthening the right of saying, not being a carbon seller anymore)

154 tàn jià " shān chóng shuǐ fù " , guó nèi tàn shì chăng réng nán " liǔ àn huā míng " (Carbon prices fluctuate, still no clear

China Prily

Daily

26-Oct-12

China Economic 2-Feb-13 prospect for domestic carbon market)

167 jiàn quán tuī dòng tàn jiāo yì fā zhăn de zhì dù (Promoting $\mathrm{a}$ sound system of carbon trading) 